\title{
Time course tissue distribution of infectious salmon anaemia virus in experimentally infected Atlantic salmon Salmo salar
}

\author{
Espen Rimstad ${ }^{1, *}$, Knut Falk $^{2}$, Aase B. Mikalsen', Ann Teig ${ }^{1}$ \\ 'Department of Pharmacology, Microbiology and Food Hygiene, Norwegian College of Veterinary Medicine, PO Box 8146, \\ Dep., N-0033 Oslo, Norway \\ ${ }^{2}$ National Veterinary Institute, PO Box 8156, Dep., N-0033 Oslo, Norway
}

\begin{abstract}
Atlantic salmon Salmo salar L. were injected intraperitoneally with infectious salmon anaemia virus (ISAV)-infective tissue homogenate to clarify the tissue distribution of ISAV in a time course study. Fish were sampled at 11 different intervals between 1 and $40 \mathrm{~d}$ post-infection (p.i.) and mid-kidney, head kidney, liver, spleen, intestine, gills, muscle and heart were tested for the presence of ISAV by reverse transcriptase polymerase chain reaction (RT-PCR). The results showed that during a disease outbreak, ISAV is present in most organs. It was possible to detect ISAV at all sampling times in at least 1 of the fish examined. However, for the first $8 \mathrm{~d}$ p.i. positive RT-PCR results were predominantly found in samples from the head kidney and mid-kidney. Fish giving positive samples after Day 13 p.i. were RT-PCR positive in most organs. These results indicated that between Days 8 to 13 p.i. considerable replication of the virus occurred, combined with wide tissue dissemination.
\end{abstract}

KEY WORDS: Infectious salmon anaemia virus (ISAV) - ISAV tissue distribution - RT-PCR detection of ISAV

\section{INTRODUCTION}

Infectious salmon anaemia virus (ISAV) is an orthomyxovirus-like virus that causes a generalised infection in Atlantic salmon Salmo salar L. Infectious saimon anaemia (ISA) was recognised as a separate disease entity in 1984 in farmed Atlantic salmon in Norway (Thorud \& Djupvik 1988) and has since been the cause of considerable economic loss to the salmon farming industry. Although previously restricted to Norway, the disease has also recently been recognised in Atlantic salmon farms on the eastern coast of Canada and in Scotland (Mullins et al. 1998, Rodger et al. 1998). Natural outbreaks of ISA have only been described in Atlantic salmon. However, it has been demonstrated experimentally that ISAV can infect brown trout Salmo trutta (Nylund \& Jakobsen 1995)

•E-mail: espen.rimstad@veths.no and rainbow trout Oncorhynchus mykiss (Nylund \& Jacobsen 1997) without producing mortality, although a lowering of the hematocrit and minor histopathological changes (only for rainbow trout) were observed.

The disease spreads slowly through an affected farm, with accumulated mortality rates of between 15 and $100 \%$ after several months. The disease is characterised by severe anaemia and leucopaenia, pale gills and haemorrhages in the eyes (Evensen et al. 1991). Gross pathological changes include ascitic fluid in the peritoneal cavity, petechiae in the viscera and congestion in the liver, spleen and proximal part of the gut (Evensen et al. 1991). Microscopically, the presence of multifocal zonal haemorrhagic necroses in the liver is considered to be typical for ISA, although haemorrhages in hematopoitic tissue and necrosis of the renal tubules can also be observed.

In order to gain a better understanding of the tissue distribution and time course of viral replication during an ISAV infection, Atlantic salmon were experimen- 
tally infected. Fish were sacrificed at 11 different intervals between Days 1 and 40 post-infection (p.i.) and several organs were tested for the presence of ISAV by reverse transcriptase polymerase chain reaction (RTPCR). The results showed that during a disease outbreak ISAV is present in large amounts in most organs.

\section{MATERIALS AND METHODS}

Experimental infection. Atlantic salmon presmolts with an average weight of about $100 \mathrm{~g}$ were obtained from a salmon hatchery where ISA had never been diagnosed. Each of 200 fish was injected intraperitoneally with $0.5 \mathrm{ml}$ ISAV-infective tissue homogenate prepared from experimentally infected salmon, as described elsewhere (Dannevig et al. 1993). The fish were kept at $12^{\circ} \mathrm{C}$ in fresh water in a $1 \mathrm{~m}^{2}$ tank. The experiment was conducted in autumn at VESO Vikan Akva Vet Research Station, Namsos, Norway.

Five fish were sacrificed at Day 0 (prior to infection), and at Days 1, 2, 5, 6, 8, 13, 16, 20, 27, 34 and 40 p.i Samples were aseptically removed from each individual fish from the mid-kidney, head kidney, liver, spleen, intestine, gills, muscle and heart and placed in separate sealed plastic bags. Particular care was taken to avoid cross-contamination between tissue samples The samples were immediately frozen at $-70^{\circ} \mathrm{C}$ and kept at this temperature until further processing.

Blood was drawn from the caudal vein using a heparinized vacutainer. Haematocrit was determined within $30 \mathrm{~min}$ of sampling by centrifugation of heparinized microcapillary tubes for $5 \mathrm{~min}$ in an Adams Autocrit centrifuge. Calculations of means of the hematocrits, 95\% confidence intervals and comparisons of means were performed using the statistical package JMP (SAS Institute Inc., Cary, NC).

Tissue preparation for RT-PCR. After thawing, the tissues samples were placed in plastic bags containing phosphate buffered saline (PBS) (approximately 10-fold the volume of the tissue samples) and were finely homogenised using a roller. Afterwards, $1 \mathrm{ml}$ of this organ suspension was mixed with $2 \mathrm{ml}$ TRIzol ${ }^{\otimes}$ Reagent (GibcoBRL, Gaithersburg, MD) and incubated at room temperature for $5 \mathrm{~min}$. This was followed by the addition of $0.4 \mathrm{ml}$ chloroform, vigorous shaking by hand for $15 \mathrm{~s}$, incubation at room temperature for 2 to $3 \mathrm{~min}$ and phase separation by centrifugation at $12000 \times g$ for $15 \mathrm{~min}$ at $4^{\circ} \mathrm{C}$. The aqueous phase was transferred to a fresh tube with $1 \mathrm{ml}$ isopropyl alcohol, incubated at room temperature for $10 \mathrm{~min}$, and centrifuged at $12000 \times \mathrm{g}$ for $10 \mathrm{~min}$ at $4^{\circ} \mathrm{C}$. The RNA pellet was washed once in $75 \%$ diethyl pyrocarbonate (DEPC) treated ethanol, then air-dried for 5 to $10 \mathrm{~min}$ and dissolved in $100 \mu \mathrm{l}$ DEPC-treated water. The concentra- tion and purity of the RNA were estimated by measuring the optical density at $260 \mathrm{~nm}\left(\mathrm{OD}_{260}\right)$ and the ratio $\mathrm{OD}_{260} / \mathrm{OD}_{280}$, respectively.

RT-PCR. The RT-PCR was performed as described by Mjaaland et al. (1997). Briefly, $2 \mu \mathrm{g}$ of RNA were used in a $20 \mu \mathrm{l}$ reverse transcriptase reaction which was incubated for $1 \mathrm{~h}$ at $37^{\circ} \mathrm{C}$. Five microlitres of the resultant cDNA were added to a $45 \mu$ PCR mix. The primers, contents of the PCR mix, and cycling profile have been described elsewhere (Mjaaland et al. 1997). The PCR products were demonstrated by electrophoresis in 3\% agarose gels (NuSieve 3:1 agarose, FMC BioProducts, Rockland, ME) followed by ethidium bromide staining.

Interpretation of PCR results. The size of the DNA fragment amplified by these primers was estimated to be $157 \mathrm{bp}$. The specificity of this fragment was tested earlier by Southern blot hybridisation using an ${ }^{32} \mathrm{P}$ labelled probe and nucleotide sequencing (Mjaaland et al. 1997). The occurrence of the $157 \mathrm{bp}$ band after electrophoresis was therefore considered to be equivalent to the presence of ISAV. In the few samples for which DNA smearing was observed in the gel lane, the RT-PCR was repeated to clarify any occluding effect this might have caused.

Each set-up included a negative and positive control, in which RNA from non-infected and ISAV-infected SHK-1 cell cultures, respectively, were used.

\section{RESULTS}

In this experiment the fish began to die at Day 20 p.i. During the $40 \mathrm{~d}$ experimental period, fish mortality accumulated to $29.2 \%$. The hematocrits for individual fish are shown in Table 1 . The average haematocrit dropped from 37.4 at Day 0 p.i. to around 30 at Day 2 p.i., and stayed at this level until Day 16 p.i. Then it began to drop again and was 17 at the end of the experiment (Fig. 1). A significant difference $195 \%$ confidence interval) between the hematocrit level for the period Days 2 to 16 p.i. and the means of the hematocrits thereafter was only found for Day 40 p.i. Hematocrits were still declining at the end of the experiment, which indicated continued development of the disease.

The PCR amplicon was easily observed as a $157 \mathrm{bp}$ band (Fig. 2). No visible bands were produced for samples taken prior to inoculation. The RT-PCR results for the different organs from Days 1 to 40 are shown in Table 1

In general, there were a few positive samples from different organs before Day 13 p.i., although all samples from the liver and heart were negative. From Days 13 to 40 p.i. most organs in most fish were positive, although in some fish all organs were negative. 
Table 1. Salmo salar. RT-PCR results and hematocrits of individual fish from Day 1 to 40

\begin{tabular}{|c|c|c|c|c|c|c|c|c|c|c|}
\hline $\begin{array}{l}\text { Days } \\
\text { p.i. }\end{array}$ & $\begin{array}{c}\text { Fish } \\
\text { no. }\end{array}$ & $\begin{array}{c}\text { Head } \\
\text { kidney }\end{array}$ & $\begin{array}{c}\text { Mid- } \\
\text { kidney }\end{array}$ & Liver & Spleen & Heart & Intestine & Gill & Muscle & Hematocrit \\
\hline 1 & $\begin{array}{l}1 \\
2 \\
3 \\
4 \\
5\end{array}$ & & & & $\begin{array}{l}+ \\
+\end{array}$ & & + & + & & $\begin{array}{l}38 \\
34 \\
40 \\
32 \\
31\end{array}$ \\
\hline 2 & $\begin{array}{l}1 \\
2 \\
3 \\
4 \\
5\end{array}$ & $\begin{array}{l}+ \\
+ \\
+\end{array}$ & $\begin{array}{l}+ \\
+\end{array}$ & & & & & + & $\begin{array}{l}+ \\
+\end{array}$ & $\begin{array}{l}33 \\
36 \\
31 \\
29 \\
31\end{array}$ \\
\hline 5 & $\begin{array}{l}1 \\
2 \\
3 \\
4 \\
5\end{array}$ & & + & & + & & & + & & $\begin{array}{l}34 \\
31 \\
37 \\
31 \\
28\end{array}$ \\
\hline 6 & $\begin{array}{l}1 \\
2 \\
3 \\
4 \\
5\end{array}$ & & + & & & & & & & $\begin{array}{l}28 \\
33 \\
31 \\
33 \\
28\end{array}$ \\
\hline 8 & $\begin{array}{l}1 \\
2 \\
3 \\
4 \\
5\end{array}$ & + & & & & & & & & $\begin{array}{l}30 \\
33 \\
31 \\
29 \\
27\end{array}$ \\
\hline 13 & $\begin{array}{l}1 \\
2 \\
3 \\
4 \\
5\end{array}$ & $\begin{array}{l}+ \\
+ \\
+\end{array}$ & $\begin{array}{l}+ \\
+ \\
+\end{array}$ & $\begin{array}{l}+ \\
+ \\
+\end{array}$ & + & $\begin{array}{l}+ \\
+ \\
+\end{array}$ & + & $\begin{array}{l}+ \\
+ \\
+\end{array}$ & $\begin{array}{l}+ \\
+ \\
+\end{array}$ & $\begin{array}{l}28 \\
33 \\
29 \\
38 \\
28\end{array}$ \\
\hline 16 & $\begin{array}{l}1 \\
2 \\
3 \\
4 \\
5\end{array}$ & $\begin{array}{l}+ \\
+ \\
+ \\
+\end{array}$ & $\begin{array}{l}+ \\
+ \\
+ \\
+\end{array}$ & $\begin{array}{l}+ \\
+ \\
+ \\
+\end{array}$ & $\begin{array}{l}+ \\
+ \\
+ \\
+\end{array}$ & $\begin{array}{l}+ \\
+ \\
+ \\
+\end{array}$ & $\begin{array}{l}+ \\
+ \\
+ \\
+\end{array}$ & $\begin{array}{l}+ \\
+ \\
+\end{array}$ & + & $\begin{array}{l}26 \\
41 \\
29 \\
26 \\
31\end{array}$ \\
\hline 20 & $\begin{array}{l}1 \\
2 \\
3 \\
4 \\
5\end{array}$ & + & + & + & + & + & + & $\begin{array}{l}+ \\
+\end{array}$ & + & $\begin{array}{l}32 \\
22 \\
35 \\
31 \\
12\end{array}$ \\
\hline 27 & $\begin{array}{l}1 \\
2 \\
3 \\
4 \\
5\end{array}$ & $\begin{array}{l}+ \\
+ \\
+ \\
+\end{array}$ & $\begin{array}{l}+ \\
+ \\
+ \\
+ \\
+\end{array}$ & $\begin{array}{l}+ \\
+ \\
+ \\
+ \\
+\end{array}$ & $\begin{array}{l}+ \\
+ \\
+ \\
+\end{array}$ & $\begin{array}{l}+ \\
+ \\
+ \\
+ \\
+\end{array}$ & $\begin{array}{l}+ \\
+ \\
+ \\
+ \\
+\end{array}$ & $\begin{array}{l}+ \\
+ \\
+ \\
+ \\
+\end{array}$ & $\begin{array}{l}+ \\
+ \\
+ \\
+\end{array}$ & $\begin{array}{r}30 \\
18 \\
28 \\
9 \\
25\end{array}$ \\
\hline 34 & $\begin{array}{l}1 \\
2 \\
3 \\
4 \\
5\end{array}$ & $\begin{array}{l}+ \\
+ \\
+ \\
+\end{array}$ & $\begin{array}{l}+ \\
+ \\
+ \\
+\end{array}$ & $\begin{array}{l}+ \\
+ \\
+ \\
+\end{array}$ & $\begin{array}{l}+ \\
+ \\
+ \\
+ \\
+\end{array}$ & $\begin{array}{l}+ \\
+ \\
+ \\
+ \\
+\end{array}$ & $\begin{array}{l}+ \\
+ \\
+\end{array}$ & $\begin{array}{l}+ \\
+ \\
+ \\
+ \\
+\end{array}$ & $\begin{array}{l}+ \\
+ \\
+ \\
+ \\
+\end{array}$ & $\begin{array}{l}25 \\
23 \\
29 \\
32 \\
35\end{array}$ \\
\hline 40 & $\begin{array}{l}1 \\
2 \\
3 \\
4 \\
5\end{array}$ & $\begin{array}{l}+ \\
+ \\
+\end{array}$ & $\begin{array}{l}+ \\
+ \\
+ \\
+ \\
+\end{array}$ & $\begin{array}{l}+ \\
+ \\
+ \\
+ \\
+\end{array}$ & $\begin{array}{l}+ \\
+ \\
+ \\
+ \\
+\end{array}$ & $\begin{array}{l}+ \\
+ \\
+ \\
+ \\
+\end{array}$ & $\begin{array}{l}+ \\
+ \\
+\end{array}$ & $\begin{array}{l}+ \\
+ \\
+ \\
+\end{array}$ & $\begin{array}{l}+ \\
+ \\
+ \\
+ \\
+\end{array}$ & $\begin{array}{r}19 \\
3 \\
21 \\
17 \\
25\end{array}$ \\
\hline Totãl & & $24 / 55$ & $27 / 55$ & $23 / 55$ & $24 / 55$ & $24 / 55$ & $19 / 55$ & $25 / 55$ & $23 / 55$ & \\
\hline
\end{tabular}




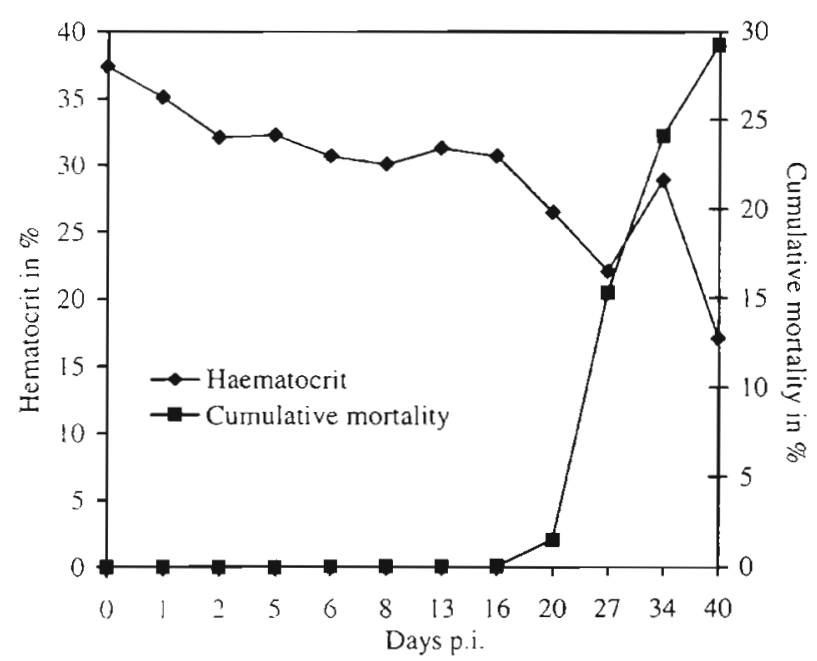

Fig. 1. Salmo salar. Average haematocrit for the 5 fish sacrificed at each sample period and cumulative mortality $(\%)$ in the experimental ISAV infection

At Day 1 p.i. a total of 4 samples from 3 fish were positive: 2 spleens, 1 gill and 1 intestine. At Day 2 p.i. 4 out of 5 fish yielded at least 1 positive sample. Four organs (head kidney, mid-kidney, gills and muscle from fish no. 3) were positive at this time, indicating that the virus was already actively replicating.

At Days 5, 6 and 8 p.i. only a few samples were positive $_{i}$ in fact, only 1 sample from 1 fish was virus RNA positive at Day 6 and Day 8. At Day 13 p.i. the situation changed significantly with most organs becoming virus RNA-positive including the liver and heart. At Days 13, 16 and 20 p.i. 2, 1 and 3 fish, respectively, were negative for the presence of ISAV RNA in all organs tested. As judged from the PCR results, there was no decline in the viral burden in the individual fish after $40 \mathrm{~d}$ of infection. The kidney gave the highest number of positive samples (27), while only 19 of the intestinal samples were virus RNA-positive. The number of positive samples obtained from muscle was similar to that for head kidney, spleen, liver, and heart.

\section{DISCUSSION}

This experiment was performed to examine the tissue distribution of ISAV in a time course study. After intraperitoneal administration in Atlantic salmon it was possible to detect ISAV at all sampling times in 1 or more of the 5 fish examined. However, the amount of viral RNA was low for the first $8 \mathrm{~d}$ p.i., with positive tis- sues predominantly found in the head and mid-kidney. Fish with positive samples after Day 13 p.i. were RTPCR positive in most organs, indicating that, between Days 8 and 13 p.i., wide tissue dissemination of the virus occurred, possibly combined with considerable replication. This is in accordance with earlier findings of Dannevig et al. (1994), in which the infectivity of organs from ISAV-infected Atlantic salmon increased from Day 11 p.i., as tested by experimental infection of salmon, and of Totland et al. (1996), who found that the infection could be transmitted from Day 7 p.i.

Two of 5 fish were RT-PCR positive in the spleen at Day 1 ; this may have been due to capture of erythrocytes with membrane-bound ISAV. Haemagglutination of Atlantic salmon erythrocytes by ISAV does not show spontaneous elution (Falk et al. 1997), i.e. ISAV bound to erythrocytes will not be released and such erythrocytes are identified as foreign and cleared from the circulation. Degradation products of erythrocytes have been observed in spleen macrophages early (at Day 7 p.i.) during the course of experimental ISAV infection (Falk et al. 1995). The positive sample at Day 1 from the intestine was probably a result of intestinal deposition of the inoculum.

Several of the fish in our experiment produced no virus RNA-positive samples at Days 13, 16 and 20 p.i., indicating that the experimental infection failed to establish itself in these individuals. There are several possible reasons for this: (1) the peritoneal cavity is an

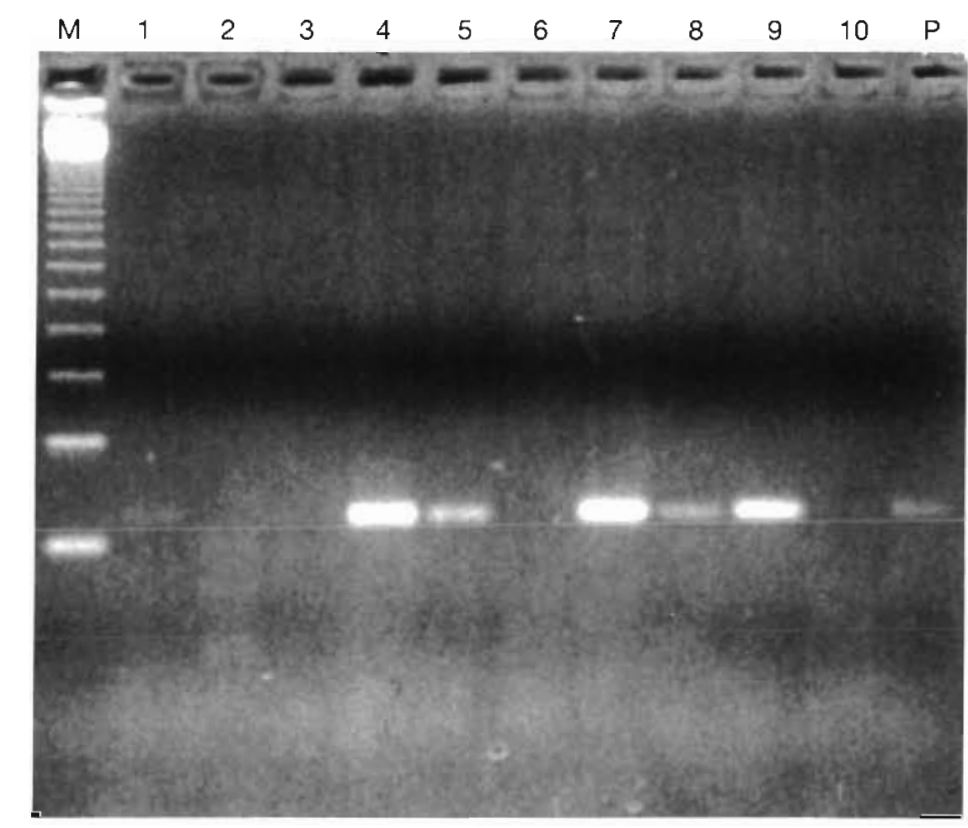

Fig. 2. Reverse transcriptase PCR products were electrophoresed in agarose gel and stained in ethidium bromide. Lane $\mathrm{M}$ : molecular size (123 basepair ladder); Ianes 1-10: target RNA from different organs detected in lanes $1,4,5,7,8$, and 9 . Lane $P$ : positive control (RNA from ISAV-infected SHK-1 cells) 
unnatural portal of entry for ISAV; (2) the dose of virus used was below the threshold value for establishment of infection; (3) certain fish were able to clear the infection; (4) the amount of virus RNA was below the sensitivity of the detection method. However, failure to develop a specific immune response capable of clearing the infection at this stage was less likely, because positive RT-PCR samples were obtained from all fish that were tested from Day 27 p.i. onwards. Establishment of ISAV infection in all fish in the tank from Day 27 p.i. may have been due to the build-up of a high infectious dose in the tank caused by the shedding of virus from infected fish. This is supported by the finding that $14 / 15$ gill samples tested positive from Day 27 p.i. onwards. However, we did not test the water for virus to confirm this. Earlier transmission experiments in which ISAV was injected into susceptible Atlantic salmon demonstrated that fish began to die 2 to 3 wk p.i., with deaths observed 10 to $12 \mathrm{~d}$ later in cohabiting fish (Dannevig et al. 1994). These time intervals may have been influenced by variables such as temperature and susceptibility of the experimental fish. As judged by our PCR results, there was no significant decline in the virus burden in most organs even after $40 \mathrm{~d}$ p.i. The possible reinfection of fish in which the original experimental infection was not detectable could confound the actual duration of the infection in each individual fish. Nevertheless, our results indicate that some individuals may harbour the virus for many weeks before succumbing to ISAV-induced disease, and that this may therefore be important in the dissemination of the infection within a farm. Therefore, destruction of ISAV-infected fish and disinfection of the premises should be carried out as soon as possible after ISAV has been detected.

The average hematocrit value showed a paradoxical rise at Day 34 p.i. compared to the 2 preceding samplings. However, there was no significant difference $(p<0.05)$ between the means of the hematocrits of these 3 samplings.

Our results imply that the target cells for ISAV are present in all or most organs. In contrast to orthomyxovirus infections in mammals, ISAV infection is not restricted to the respiratory system. By electronmicroscopy, budding of ISAV has been localised to endothelial cells of blood vessels in several organs (Hovland et al. 1994, Nylund et al. 1995, Koren \& Nylund 1997). Endothelial cells may therefore be target cells for ISAV. However, ISAV is a close relative of the influenza viruses for which tissue tropism and pathogenicity are determined by a combination of viral and host factors. Haemagglutinin is an important determinant for host cell range for orthomyxoviruses because of its function in receptor recognition and attachment. Both haemagglutinating and haemadsorb- ing properties have been described for ISAV (Falk et al. 1997), thus making it likely that the haemagglutinin proteins are also important determinants of the host cell range for ISAV. The structure of the viral receptors and the availability and tissue distribution of proteases capable of activating the fusogenic property of the haemagglutinin are essential factors in this context (Tashiro \& Rott 1996). The replication of ISAV is influenced by protease activity as indicated by the increased yield of infectious virus in cell culture medium after cultivation of ISAV in the presence of trypsin (Falk et al. 1997). The wide tissue distribution of ISAV suggests that, if ISAV infectivity is indeed dependent on proteolytic activation of its membrane proteins, then this cleavage is performed by commonly occurring proteases. This may also partly explain the virulence of ISAV, the mortality being as high as $100 \%$ in some ISA outbreaks (Thorud 1991).

The ISAV-induced disease in this experiment followed a more protracted course than the typical, acute form of ISA. The protracted form of ISA is characterised by a longer incubation period and lower fish mortality rate compared to the acute form. Furthermore, there is a tendency for haemorrhages and oedema to be more pronounced, while darkening of the liver is seldom observed. The reasons for the existence of different forms of the disease are obscure, but host-related or environmental factors such as fluctuation in water temperature and season are probably significant. Other experimental infections in which the inoculated infectious material has originated from the same batch have given both forms of the disease ( $\mathrm{K}$. Falk pers. obs.), thus indicating that the viral factor is of minor importance in determining the form the disease will take. Both natural and experimental protracted ISAV outbreaks have normally been observed in the autumn (K. Falk pers. obs.).

Samples from the gills gave variable positive results before Day 13 p.i., but were constantly RT-PCR positive thereafter (except for 2 fish) from fish yielding at least 1 RT-PCR positive test from any other organ. Therefore, the gills may be important as a portal of entry and for shedding the virus, as has been suggested by others (Totland et al. 1996). This does not, however, exclude other routes of infection, since infectivity has been found in skin mucus, faeces, and urine (Totland et al. 1996). The possible reinfection of the fish that may have occurred in our experiment also lends support to the gills as an infection route. Longterm survival of ISAV in an aquatic environment at neutral $\mathrm{pH}$ has been reported (Falk et al. 1997). Oral entry is less likely as ISAV loses infectivity on exposure to $\mathrm{pH} 4.0$ for $30 \mathrm{~min}$ (Falk et al. 1997). The optimum $\mathrm{pH}$ for Inaximum proteolytic activity in the stomach of predatory fish has been reported to be 2.0 (Munilla- 
Moran \& SaboridoRey 1996). Sea lice, which have been suggested to be vectors of ISAV (Nylund et al. 1994), were not observed in this experiment.

Typical pathological changes found in the liver due to ISAV infection have been described (Evensen et al. 1991). Ultrastructural changes observed by transmission electron microscopy first occur at Day 4 p.i. in the perisinusoidal macrophages (Speilberg et al. 1995). However, no positive RT-PCR results were obtained from liver samples before $13 \mathrm{~d}$ p.i., suggesting that these ultrastructural changes in the liver occur prior to detection of virus by RT-PCR. In contrast, gross and light microscopic changes, occur from Day 18 p.i. (Speilberg et al. 1995), i.e. after virus can be detected by RT-PCR.

RT-PCR has been shown to be an efficient alternative to virus isolation for the detection of influenza viruses in clinical specimens from several mammalian species (Cherian et al. 1994, Donofrio et al. 1994), and the method is particularly effective for the identification of influenza virus in samples obtained late in the course of infection (Cherian et al. 1994). Our results demonstrate that RT-PCR can detect ISAV in specimens that are easy to collect, and is thus a suitable tool for the study of the pathogenesis and epidemiology of ISAV infection in salmon.

\section{LITERATURE CITED}

Cherian T, Bobo L, Steinhoff MC, Karron RA, Yolken RH (1994) Use of PCR-enzyme immunoassay for identification of influenza A virus matrix RNA in clinical samples negative for cultivable virus. J Clin Microbiol 32:623-628

Dannevig BH, Falk K, Krogsrud J (1993) Leukocytes from Atlantic salmon, Salmo salar L., experimentally infected with infectious salmon anemia (ISA) exhibit an impaired response to mitogens. J Fish Dis 16:351-359

Dannevig $\mathrm{BH}$, Falk K, Skjerve $\mathrm{E}$ (1994) Infectivity of internal tissues of Atlantic salmon, Salmo salar L., experimentally infected with the etiologic agent of infectious salmon anemia (ISA). J Fish Dis 17:613-622

Donofrio JC, Coonrod JD, Chambers TM (1994) Diagnosis of equine influenza by the polymerase chain reaction. $J$ Vet Diagn Invest 6:39-43

Evensen O, Thorud KE, Olsen YA (1991) A morphological study of the gross and light microscopic lesions of infectious anaemia in Atlantic salmon (Salmo salar). Res Vet Sci $51: 215-222$

Falk K, Press CM, Landsverk T, Dannevig BH (1995) Spleen and kidney of Atlantic salmon (SaImo salar L.) show histochemical changes eariy in the course of experimentally induced infectious salmon anaemia (ISA). Vet Immunol Immunopathol 49:115-126

Editorial responsibility: Jo-Ann Leong,

Corvallis, Oregon, USA
Falk K, Namork E, Rimstad E, Mjaaland S, Dannevig BH (1997) Characterization of infectious salmon anemia virus, an orthomyxo-like virus isolated from Atlantic salmon (Salmo salar L.). J Virol 71:9016-9023

Hovland T, Nylund A, Watanabe K, Endresen C (1994) Observation of infectious salmon anemia virus in Atlantic salmon, Salmo salar L. J Fish Dis 17:291-296

Koren CWR. Nylund A (1997) Morphology and morphogenesis of infectious salmon anaemia virus replicating in the endothelium of Atlantic salmon Salmo salar. Dis Aquat Org 29:99-109

Mjaaland S, Rimstad E, Falk K, Dannevig BH (1997) Genomic characterization of the virus causing infectious salmon anemia in Atlantic salmon (Salmo salar L.): an orthomyxolike virus in a teleost. J Virol 71:7681-7686

Mullins JE، Groman D, Wodowska D (1998) Infectious samon anaemia in salt water Atlantic salmon (Salmo salar L.) in New Brunswick, Canada. Bull Eur Assoc Fish Pathol 18: $110-114$

MunillaMoran R, SaboridoRey F (1996) Digestive enzymes in marine species 1 Proteinase activities in gut from redfish (Sebastes mentella), seabream (Sparus aurata) and turbot (Scophthalmus maximus). Comp Biochem Physiol B Comp Biochem Mol Biol 113:395-402

Nylund A, Jakobsen P (1995) Sea-trout as a carrier of infectious salmon anemia virus. J Fish Biol 47:174-176

Nylund A, Hovland T, Hodneland K, Nilsen F, Lovik P (1994) Mechanisms for transmission of infectious salmon anemia (ISA). Dis Aquat Org 19:95-100

Nylund A, Hovland T, Watanabe K, Endresen C (1995) Presence of infectious salmon anemia virus (ISAV) in tissues of Atlantic salmon, Salmo salar L., collected during 3 separate outbreaks of the disease. J Fish Dis 18: $135-145$

Nylund A, Kvenseth AM. Krossoy B, Hodneland K (1997) Replication of the infectious salmon anaemia virus (ISAV) in rainbow trout, Oncorhynchus mykiss (Walbaum). J Fish Dis 20:275-279

Rodger HD, Turnbull T, Muir F, Millar S, Richards RH (1998) Infectious salmon anaemia (ISA) in the United Kingdom Bull Eur Assoc Fish Pathol 18:115-116

Speilberg L, Evensen O, Dannevig BH (1995) A sequential study of the light and electron microscopic liver lesions of infectious anemia in Atlantic salmon (SaImo salar L.). Vet Pathol 32:466-478

Tashiro M, Rott $\mathrm{R}$ (1996) The role of proteolytic cleavage of viral glycoproteins in the pathogenesis of influenza virus infections. Semin Virol 7:237-243

Thorud KE (1991) Infectious salmon anaemia. Transmission trials. Haematological, clinical and morphological investigations. PhD thesis, Norwegian College of Veterinary Medicine, Oslo

Thorud K, Djupvik HO (1988) Infectious anaemia in Atlantic salmon (Salmo salar L.). Bull Eur Assoc Fish Pathol 8: $109-111$

Totland GK, Hjeltnes BK, Flood PR (1996) Transmission of infectious salmon anaemia (ISA) through natural secretions and excretions from infected smelts of Atlantic salmon Salmo salar during their presymptomatic phase. Dis Aquat Org 26:25-31

Submitted: October 10, 1998; Accepted: January 20, 1999

Proofs received from author(s): April 19, 1999 